\title{
Evaluation of API 20 STREP system for identifying Listeria species
}

\author{
A P MacGOWAN, R J MARShALL, D S REEVES The Department of Medical Microbiology, \\ Division of Pathology, Southmead Hospital, Westbury on Trym, Bristol
}

SUMMARY The API 20 STREP system was used to identify 146 known strains from seven species of the genus Listeria, including both pathogenic and environmental strains. The gallery was easy to use and tests, with the exception of leucine arylamidase (LAP) and starch fermentation (AMD), were simple to interpret. Identification to genus level was satisfactory but differentiation between species was poor. Using the API 20 STREP the haemolytic species $L$ monocytogenes, seeligeri, and ivanovii could easily be differentiated from the non-haemolytic species $L$ welshimeri, innocua, grayii and murrayi. Of the haemolytic species, $L$ monocytogenes could not be distinguished from $L$ seeligeri but $L$ ivanovii could be separated from the two other haemolytic species because it fermented ribose. Nonhaemolytic $L$ welshimeri could not be differentiated from non-haemolytic $L$ innocua, but mannitol and ribose fermenting non-haemolytic $L$ grayi and $L$ murrayi were easily differentiated from the other two non-haemolytic species.

The API 20 STREP identified Listeria in four hours and therefore might be used for rapid identification of strains causing infection in man. It would, however, not be useful to identify environmental isolates when speciation is important.

The incidence of human listeriosis is increasing in the United Kingdom. ${ }^{1}$ Methods for isolation of Listeria have improved ${ }^{2}$ and there is greater understanding of the pathogenesis of the infection and its association with the presence of Listeria in food. The use of rapid rather than traditional methods for identification of Listeria species, however, may result in misidentification. ${ }^{2-4}$ The API $50 \mathrm{CH}$ and API-ZYM systems have already been used to identify Listeria $^{4}$ but neither of these are widely used in the United Kingdom. The current API 20 STREP system was introduced before the advances in Listeria taxonomy were made in the early $1980 \mathrm{~s}^{2}$ We therefore examined the ability of API 20 STREP to identify Listeria species.

\section{Material and methods}

One hundred and forty six Listeria species were used; 119 strains of Listeria monocytogenes, eight strains of Listeria seeligeri, six strains of Listeria ivanovii, four strains of Listeria welshimeri, seven strains of Listeria innocua and one strain each of Listeria grayi and murrayi. They were stored on blood agar or Dorset egg

Accepted for publication 16 November 1988 slopes at $4^{\circ} \mathrm{C}$ for up to 18 months before being tested. The original isolates were obtained from our own laboratory, Professor R Postlethwaite, department of bacteriology, University of Aberdeen, Dr R Fenton, School of Agriculture, Aberdeen, The National Collection of Type Cultures and Dr J McLauchlin, Central Public Health Laboratory, Colindale, London, Professor H P R Seeliger, University of Würzburg, West Germany, and Dr J Rocourt, Pasteur Institute, Paris, France.

The organisms were taken from stored cultures on to blood agar plates and incubated at $37^{\circ} \mathrm{C}$ for $18-24$ hours. Individual colonies were then streaked on to blood agar plates and incubated anaerobically at $37^{\circ} \mathrm{C}$ for 18-24 hours. From the resultant growth a heavy suspension was made in $2 \mathrm{ml}$ sterile distilled water and used to inoculate the first half of the API 20 STREP strip (tests acetoin production (VP) to arginine dihydrolase (ADH)). About $0.5 \mathrm{ml}$ of the same suspension was added to the ampoule of API 20 STREP medium provided and then inoculated into the second half of the strip (tests ribose fermentation (RIB) to glycogen fermentation (GLYG), and on to sheep and horse blood agars to test for haemolysis. Mineral oil was used to overlay cupules arginine dihydrolase (ADH) to glycogen fermentation (GLYG). After four 
hours' incubation at $37^{\circ} \mathrm{C}$ reagents ZYM A and ZYM $B$ were added to cupules pyrrolidonylarylamidase (PYRA) to LAP; ninhydrin was added to the hyppurate hydrolysis (HIP) cupule and VP and VP 2 reagents were added to the VP cupule (reagents supplied by API). After 10 minutes the results obtained in the tests were then interpreted according to the manufacturer's guide sheet. Haemolysis was assessed on both horse and sheep blood after overnight culture.

\section{Results}

Aesculin (ESC), ADH, and carbohydrate reactions were read at four and 24 hours, and were for the most part easily scored. The profile numbers given by each species are shown in table 1. After four hours' incubation $56 \%$ of strains gave positive LAP tests, but this test was difficult to interpret. In contrast, the VP, HIP, ESC and trebalose fermentation (TRE) tests were easier to read at four hours and the reactions universally positive. AMD fermentation was often difficult to interpret and therefore scored as $+/-$ for calculating profile numbers (table 2 ). API profiles read at four hours showed that all $L$ monocytogenes strains gave good, very good, or excellent identification (table 1). At 24 hours' incubation ESC, TRE, and AMD were all positive and a variable number of strains fermented lactose, raffinose, and ribose. Eighty per
Table 1 Four hour API 20 STREP number profiles

\begin{tabular}{|c|c|c|c|c|}
\hline \multirow{2}{*}{$\frac{\text { Profile }}{7000010}$} & \multirow{2}{*}{$\begin{array}{l}\text { Strain } \\
\text { L monocytogenes } \\
\text { L seeligeri }\end{array}$} & \multicolumn{2}{|c|}{$\begin{array}{l}\text { Per cent } \\
\text { giving profile }\end{array}$} & \multirow{2}{*}{$\begin{array}{l}\begin{array}{l}\text { APILAB } \\
\text { software }\end{array} \text { ID } \\
\text { Good }\end{array}$} \\
\hline & & $13 \cdot 3$ & (16) & \\
\hline $7000010 / 1$ & $\begin{array}{l}\text { L monocytogenes } \\
L \text { seeligeri } \\
L \text { welshimeri } \\
\text { L ivanovii }\end{array}$ & $\begin{array}{l}16 \cdot 6 \\
25 \cdot 0 \\
25 \cdot 0 \\
33 \cdot 3\end{array}$ & $\begin{array}{l}(20) \\
(2) \\
(1) \\
(2)\end{array}$ & \\
\hline 7000011 & $\begin{array}{l}L \text { monocytogenes } \\
L \text { innocua }\end{array}$ & $\begin{array}{r}7 \cdot 5 \\
14 \cdot 3\end{array}$ & $\begin{array}{l}(9) \\
(1)\end{array}$ & Very good \\
\hline 7040010 & $\begin{array}{l}\text { L monocytogenes } \\
L \text { seeligeri } \\
L \text { ivanovii } \\
L \text { innocua }\end{array}$ & $\begin{array}{l}13 \cdot 3 \\
12 \cdot 0 \\
33 \cdot 3 \\
14 \cdot 3\end{array}$ & $\begin{array}{l}(16) \\
(1) \\
(2) \\
(1)\end{array}$ & Very good \\
\hline $7040010 / 1$ & $\begin{array}{l}\text { L monocytogenes } \\
\text { L seeligeri } \\
\text { L welshimeri } \\
\text { L ivanovii } \\
\text { L innocua }\end{array}$ & $\begin{array}{l}40 \cdot 0 \\
25 \cdot 0 \\
50 \cdot 0 \\
33 \cdot 3 \\
71 \cdot 4\end{array}$ & $\begin{array}{l}(48) \\
(2) \\
(2) \\
(2) \\
(5)\end{array}$ & \\
\hline 7040011 & $\begin{array}{l}\text { L monocytogenes } \\
L \text { seeligeri } \\
L \text { welshimeri }\end{array}$ & $\begin{array}{r}8 \cdot 3 \\
25 \cdot 0 \\
25 \cdot 0\end{array}$ & $\begin{array}{r}(19) \\
(2) \\
(1)\end{array}$ & Excellent \\
\hline $7040110 / 1$ & L grayi/murrayi & $100 \cdot 0$ & (2) & Very doubtful \\
\hline
\end{tabular}

*APILAB software will only identify $L$ monocytogenes.

cent of the 146 strains fermented lactose and one strain fermented raffinose. All of the $L$ ivanovii strains and both $L$ murrayi and $L$ grayi strains fermented ribose;

Table 2 API 20 STREP profiles of Listeria species read after four and 24 hours' incubation

\begin{tabular}{|c|c|c|c|c|c|c|}
\hline \multirow{3}{*}{$\frac{\text { Species }}{\text { L monocytogenes }}$} & \multicolumn{3}{|l|}{ Four hour } & \multicolumn{3}{|l|}{24 hour } \\
\hline & \multirow{2}{*}{$\begin{array}{l}\text { Profile } \\
7000010 \\
7000010 / 1^{*} \\
7000011 \\
7040010 \\
7040010 / 1 \\
7040011\end{array}$} & \multicolumn{2}{|c|}{ Per cent strains } & \multirow{2}{*}{$\begin{array}{l}\text { Profile } \\
7000015 \\
7000415 \\
7040015 \\
7040415 \\
7040455\end{array}$} & \multicolumn{2}{|c|}{ Per cent strains } \\
\hline & & $\begin{array}{r}13 \cdot 3 \\
16 \cdot 6 \\
7 \cdot 5 \\
13 \cdot 8 \\
40 \cdot 0 \\
8 \cdot 3\end{array}$ & $\begin{array}{r}(16) \\
(20) \\
(9) \\
(16) \\
(48) \\
(10)\end{array}$ & & $\begin{array}{r}9.2 \\
30.0 \\
14 \cdot 2 \\
45.0 \\
0.8\end{array}$ & $\begin{array}{l}(11) \\
(36) \\
(17) \\
(54) \\
(1)\end{array}$ \\
\hline L seeligeri & $\begin{array}{l}7000010 \\
7000010 / 1 \\
7040010 \\
7040010 / 1 \\
7040011\end{array}$ & $\begin{array}{l}12 \cdot 5 \\
25 \cdot 0 \\
12 \cdot 5 \\
25 \cdot 0 \\
25 \cdot 0\end{array}$ & $\begin{array}{l}(1) \\
(2) \\
(1) \\
(2) \\
(2)\end{array}$ & $\begin{array}{l}7000415 \\
7002415 \\
7040015 \\
7040415\end{array}$ & $\begin{array}{l}25 \cdot 0 \\
12 \cdot 5 \\
25 \cdot 0 \\
37 \cdot 5\end{array}$ & $\begin{array}{l}(2) \\
(1) \\
(2) \\
(3)\end{array}$ \\
\hline$L$ welshimeri & $\begin{array}{l}7000010 / 1 \\
7040010 / 1 \\
7040011\end{array}$ & $\begin{array}{l}25.0 \\
50.0 \\
25.0\end{array}$ & $\begin{array}{l}(1) \\
(2) \\
(1)\end{array}$ & $\begin{array}{l}7000411 \\
7040411\end{array}$ & $\begin{array}{l}25.0 \\
75.0\end{array}$ & $\begin{array}{l}(1) \\
(3)\end{array}$ \\
\hline Livanovii & $\begin{array}{l}7000010 / 1 \\
7040010 \\
7040010 / 1\end{array}$ & $\begin{array}{l}33 \cdot 0 \\
33 \cdot 0 \\
33 \cdot 0\end{array}$ & $\begin{array}{l}(2) \\
(2) \\
(2)\end{array}$ & $\begin{array}{l}7002015 \\
7002415 \\
7042015 \\
7042415 \\
7042455\end{array}$ & $\begin{array}{l}16 \cdot 6 \\
16 \cdot 6 \\
16 \cdot 6 \\
33 \cdot 0 \\
16 \cdot 6\end{array}$ & $\begin{array}{l}(1) \\
(1) \\
(1) \\
(2) \\
(1)\end{array}$ \\
\hline$L$ innocua & $\begin{array}{l}7000011 \\
7040010 \\
7040110 / 1\end{array}$ & $\begin{array}{l}14 \cdot 3 \\
14 \cdot 3 \\
71 \cdot 4\end{array}$ & $\begin{array}{l}(1) \\
(1) \\
(5)\end{array}$ & $\begin{array}{l}7000411 \\
7040411\end{array}$ & $\begin{array}{l}14 \cdot 3 \\
87 \cdot 1\end{array}$ & $\begin{array}{l}(1) \\
(6)\end{array}$ \\
\hline L gray/murrayi & $7040110 / 1$ & $100 \cdot 0$ & (2) & 7042511 & $100 \cdot 0$ & (2) \\
\hline
\end{tabular}

*AMD test equivocal therefore scored $0 / 1$. 
Table 324 hour API 20 STREP number profile

\begin{tabular}{|c|c|c|c|c|}
\hline Profile & Strain & $\begin{array}{l}\text { Perce } \\
\text { giving }\end{array}$ & $\begin{array}{l}\text { pt } \\
\text { profile }\end{array}$ & $\begin{array}{l}A P I L A B \\
\text { software }{ }^{*} I D\end{array}$ \\
\hline $\begin{array}{l}7000015 \\
7000415\end{array}$ & $\begin{array}{l}\text { L monocytogenes } \\
\text { L monocytogenes } \\
\text { L seeligeri }\end{array}$ & $\begin{array}{r}9 \cdot 2 \\
30 \cdot 0 \\
25 \cdot 0\end{array}$ & $\begin{array}{r}(11) \\
(36) \\
(2)\end{array}$ & $\begin{array}{l}\text { Excellent } \\
\text { Very good }\end{array}$ \\
\hline 7000411 & $\begin{array}{l}L \text { welshimeri } \\
\text { L innocua }\end{array}$ & $\begin{array}{l}25 \cdot 0 \\
14 \cdot 3\end{array}$ & (1) & Very good \\
\hline $\begin{array}{l}7002015 \\
7002415\end{array}$ & $\begin{array}{l}\text { L ivanovii } \\
\text { L ivanovii } \\
\text { L seeligeri }\end{array}$ & $\begin{array}{l}16.6 \\
16 \cdot 6 \\
12.0\end{array}$ & $\begin{array}{l}\text { (1) } \\
\text { (1) } \\
\text { (1) }\end{array}$ & $\begin{array}{l}\text { Good } \\
\text { Good }\end{array}$ \\
\hline 7040015 & $\begin{array}{l}\text { L monocytogenes } \\
L \text { seeligeri }\end{array}$ & $\begin{array}{l}14 \cdot 2 \\
25 \cdot 0\end{array}$ & $\begin{array}{r}(17) \\
(2)\end{array}$ & Excellent \\
\hline 7040411 & $\begin{array}{l}L \text { welshimeri } \\
L \text { innocua }\end{array}$ & $\begin{array}{l}75 \cdot 0 \\
87 \cdot 7\end{array}$ & $\begin{array}{l}\text { (3) } \\
\text { (6) }\end{array}$ & Excellent \\
\hline 7040415 & $\begin{array}{l}L \text { monocytogenes } \\
L \text { seeligeri }\end{array}$ & $\begin{array}{l}45 \cdot 0 \\
38 \cdot 0\end{array}$ & $\begin{array}{r}(54) \\
(3)\end{array}$ & Excellent \\
\hline $\begin{array}{l}7040455 \\
7042015 \\
7042415 \\
7042455 \\
7042511\end{array}$ & $\begin{array}{l}\text { L monocytogenes } \\
\text { L ivanovii } \\
\text { L ivanovii } \\
\text { L ivanovii } \\
\text { L grayi/murrayi }\end{array}$ & $\begin{array}{r}0.8 \\
16 \cdot 6 \\
33 \cdot 3 \\
16 \cdot 6 \\
100 \cdot 0\end{array}$ & $\begin{array}{l}\text { (1) } \\
(1) \\
(2) \\
(1) \\
(2)\end{array}$ & $\begin{array}{l}\text { Very doubtful } \\
\text { Very good } \\
\text { Good } \\
\text { Very doubtful } \\
\text { Very doubtful }\end{array}$ \\
\hline
\end{tabular}

*APILAB software will only identify $L$ monocytogenes.

none of the other species except one strain of $L$ seeligeri was reactive in this test. All strains of $L$ monocytogenes, seeligeri, and ivanovii tested were haemolytic on horse and sheep blood agar, while none of the L innocua, welshimeri, grayi and murrayi strains produced detectable haemolysins. API profiles after 24 hours gave good, very good, or excellent identification for all but one strain of $L$ monocytogenes (the raffinose fermenter), but, as the APILAB software does not recognise other Listeria species, $L$ monocytogenes can be misidentified (table 3 ).

\section{Discussion}

Rocourt and Catmel reported that $82 \%$ of their 70 Listeria strains were LAP positive compared with only $56 \%$ in this study and $97 \%$ on the API data base. ${ }^{4}$ These differences may be related to difficulty in interpreting the test. Lactose fermentation was reported with $90 \%$ of strains using the API $50 \mathrm{CH}^{4}$ and 95 $100 \%$ using conventional methods. ${ }^{56}$ Eighty per cent of our strains were lactose fermenters, which is in keeping with those observations. Similarly, only $0.8 \%$ of the $L$ monocytogenes we tested fermented raffinose; previously raffinose fermentation has been reported to be rare. ${ }^{7}$ Ribose was fermented by all five strains of $L$ ivanovii while no $L$ monocytogenes and only one strain of $L$ seeligeri fermented this carbohydrate. Ribose fermentation therefore deserves further investigation as a differential test for speciation of Listeria.

Haemolysis around Listeria colonies is useful in differentiating between species because all the $L$ monocytogenes, $L$ ivanovii, and $L$ seeligeri strains we tested were haemolytic on both sheep and horse agar while $L$ welshimeri, $L$ innocua, $L$ grayi and $L$ murrayi were not. This is in keeping with a considerable volume of reported work. ${ }^{4}$ Of the haemolytic species, $L$ seeligeri cannot be differentiated from $L$ monocytogenes by the use of the API 20 STREP, but $L$ ivanovii can as it ferments ribose. The non-haemolytic species $L$ innocua and $L$ welshimeri cannot be differentiated by API 20 STREP but the non-haemolytic, mannitol and ribose fermenting $L$ grayi and $L$ murrayi are easily differentiated from other Listeria spp. The API 20 STREP is thus adequate to identify Listeria to the genus level and this can be achieved in four hours.

The APILAB software package is out of date with regard to Listeria taxonomy, however, and the strip is not especially useful for speciation of Listeria. This is important when identifying environmental isolates such as those found in food stuffs, where $L$ monocytogenes is not the only Listeria isolated. Most, if not all, Listeria causing disease in man in the United Kingdom, however, are likely to be $L$ monocytogenes, and the API 20 STREP may be of greatest use in laboratories which do not stock the range of conventional biochemical tests required for provisional identification. ${ }^{2}$ Referral to a central reference laboratory for serotyping, speciation, and, if necessary, phage typing, is recommended.

\section{References}

1 MacLaughlin J. Listeria monocytogenes recent advances in taxonomy and epidemiology of Listeriosis in humans. $J$ Appl Bacteriol 1987;63:1-11.

2 Lamont RJ, Postlethwaite R, MacGowan AP. Listeria monocytogenes and its role in human infection: a review. $J$ Infect 1988;17:7-28.

3 MacGowan A, Marshall R, Reeves D. False positive agglutinations with Listeria monocytogenes using a commercial kit for Lancefield grouping of B haemolytic Streptococci. Eur J Clin Microbiol 1988;7:208-10.

4 Rocourt J, Catmel B. Caracterisation biochimique des deux genres Listeria. Zbl Bakt Hyg A 1985;260:221-31.

5 Wetzler TF, Freeman NR, French MLV, Renowski LA, Eveland WC, Carver OJ. Biological characterization of Listeria monocytogenes. Health Lab Sci 1968;5:46-62.

6 Wilkinson BJ, Jones D. A numerical taxonomic survey of Listeria and related bacteria. J Gen Microbiol 1977;98:399-421.

7 Seeliger HPR, Jones D. Genus Listeria. In: Sneath PHA, ed. Bergey's manual of systematic Bacteriology. Vol 2. London: Williams and Wilkins, 1986:1235-45.

Requests for reprints to: Dr A P MacGowan, Senior Registrar, Department of Medical Microbiology, Southmead Hospital, Westbury-on-Trym, Bristol BS10 5NB, England. 